Windelband, Wilhelm; Günther, Siegmund: Geschichte der antiken Naturwissenschaft und Philosophie

B.

\title{
Geschichte der alten Philosophie
}

von

Dr. W. Windelband,

ordent1. Professor der Philosophie an der Universität Strassburg. 